\title{
Monitoring Settlements Growth and Development in Algiers City Eastern Area
}

\section{Azzeddine Bellout}

University of Bouira

\section{Eric Vaz}

Ryerson University

Bruno Damásio ( $\nabla$ bdamasio@novaims.unl.pt)

Universidade Nova de Lisboa

\section{Research Article}

Keywords: Monitoring, Urbanization, Algiers, City eastern area, land-use, Settlements growth, Landsat images

Posted Date: February 17th, 2021

DOI: https://doi.org/10.21203/rs.3.rs-187885/v1

License: (c) (i) This work is licensed under a Creative Commons Attribution 4.0 International License. Read Full License 


\section{Abstract}

Monitoring change detection in urban land use/land use is essential as it pertains to one of the main environmental change drivers, leading to urban pressures impacting cultivated areas. Algiers' eastern area is one of the critical areas of Algiers' state, and it is affected by the growth and development of the composing residential areas. This research aims to analyze the current issues, including aspects of land use, residential patterns, residential development directions, and characteristics of the communities in residential growth areas. We used Landsat 8 Operational Land Imager (OLI) and Thermal Infrared Sensor (TIRS) data as the primary data source, and maps and statistical data as the secondary. The annual growth of urban land has been studied over the past six years in Algiers' eastern area. Descriptive statistics and spatial analysis allowed assessing the data further. Results indicate that there has been a $100 \%$ expansion of the residential regions during the decade from 2014 to 2020 . Population in the expansion areas increased by $2 \%$. Future studies should understand the impact of rapid urban lands on social, economic, and environmental sustainability. It will also close the gap between currently available data sources, especially regarding the lack of reliable data and environmental and urban planning for Algiers' municipality. This aids directly in developing experimental models to predict future changes of land with great statistical confidence.

\section{Introduction}

Urban growth dynamics are a complex process involving a range of physical and functional changes to the built-in field(Sahana, Hong \& Sajjad, 2018), in which residential growth and development are. Residential is generally called a settlement and it is specifically referred to as a house(Hammond C W, 1985; Hudson, 1974). The population growth rate is the main factor affecting the city's physical expansion and land consumption(Bagheri \& Tousi, 2017). Urban expansion characteristics are often locally defined, based on determinants such as economic, social, demographic, and planning. In general, the rate of urbanization increases with twice the population growth rate (Seto, Fragkias, Güneralp \& Reilly, 2011). Single concentration in certain areas without others is one of the main problems that cause the unequal imbalance of service centers.

Meanwhile, the main reason for individuals choosing a residential location is often access to employment opportunities. It makes the downtown area more conducive to the availability of decisionmaking centers, service activities, and social infrastructure such as health and education centers (Donaghy, 2013). But once people are wealthy enough to choose where they want to live and which mode of transportation they want, they tend to live far from city centers.

Urban growth also implies changes in land use (Patino and Duque, 2013). In this paper, the built-up area is defined as having residential, commercial, and industrial uses. Therefore, the city growth trend can be tracked based on the residential growth trend. Green spaces (parks) often turn into built-up areas. The rapid and erratic expansion of the city, driven by economic growth, is the main reason for the loss of parks and urban environmental damage in Algeria. One of the most significant urban sprawl 
consequences is land-use change (Aprillia and Pigawati, 2018). Consequently, it becomes imperative that the competent authorities take the necessary measures to monitor urban growth.

The high population growth rate is one of the main reasons for many of Algeria's current urban problems, and the increasing need for housing is the main issue. Weak law enforcement and low public awareness of land use plans lead to the misuse of space. The development of urban residential areas is usually controlled through policy instruments such as master (spatial) plans and development plans (Porter, 2012; Richardson, 1993; Werna, 1998). Spatially the residential regions of the world may change; However, spatial change patterns may vary along with the driving factors(Mahavir, 1996; Sarkar, 2010).

Residential growth is dependent accessibility to services and amenities in the city centre (Bitta Pigawati, Yuliastuti \& Mardiansjah, 2019). This aspect may have led to civilian neighborhoods in the outskirts of Algiers being forced to be established on unsuitable land, e.g. disaster-prone land. Residential areas are often granted to low-income community members in developing countries (Keivani \& Werna, 2001). This is not a fruitful procedure. For example, in Ireland, the planning authorities propose that the density of housing in large cities (with populations greater than 5,000 ) should be increased in order to create a sustainable residential model in a suitable area (Government of Ireland, 2009).

Sweden has introduced new urban planning measures related to housing construction time-efficiency policies in order to combat housing shortages in development (Granath Hansson, 2017). The appeal of the Algiers Metro region has contributed to the fast rise and physical development of the urban footprint.

This area, originally a residential area, has evolved into various uses such as offices, commercial uses, and call centers. All of this contributed to high population density and rapid demographic changes. The population of state Algiers reached 3 million inhabitants in 2016, distributed in an area of $1190 \mathrm{~km}^{2}$. Therefore, the population density of $5883 \mathrm{P} / \mathrm{km}^{2}$ (National Office of Statistics, 2018).

Together with the expansion of Algiers, the suburban areas are expanding exponentially and sprawling This ineffectively managed significant growth, with the problems inherent in the megalopolis of a developing country, has caused the Algerian agglomeration to become unwieldy. Governments are no longer in a position to provide their 6 million inhabitants with reliable electricity supply, orderly waste management, decent transport or protection from seismic risks. Nonetheless, the official authorities acknowledge that "the uncontrolled, even anarchic development of large urban areas generates very high economic costs as well as the deterioration of the living environment of citizens" (Rapport de GGA, 1998). As some studies on wider spatial dynamics have indicated, this phenomenon may threaten the sustainability of development. Therefore, we may ask: what are the features and patterns of settlement growth and development in the eastern region of Algiers? Consequently, the main objective of this study 
is to analyze and understand residential growth and development in the eastern part of the city of Algiers and to influence the growth and development of the compositional residential areas, particularly in the eastern part of the city. The primary focus of this study is to comprehend current issues, including aspects of land use, directions for residential development, and community characteristics in residential growth areas. Focusing on urbanization, development trends and features of residents in the area of urbanization for six years (2014-2020).

\section{Study Area}

Located on the Mediterranean coast in northern Africa, Algiers, the capital of Algeria, has geographical coordinates of $36^{\circ} 42^{\prime} \mathrm{N}$ and $3^{\circ} 09^{\prime} \mathrm{E}$, as shown in Fig. 1. It has a population of three million and occupies $1190 \mathrm{~km} 2$ of surface area (Bouhennache, Bouden \& Taleb, 2014). Urban spaces have been increasing at a significant rate over the last ten years, particularly in the east, west, and south of Algiers City, reducing cultivated spaces and Bare Field land. The area selected for study in the eastern region of Algiers consists of ten municipalities (Mohammadia, Beb Ezzouar, Berdj El Kiffan, Dar El Beida, Rouiba, Berdj El Bahri, El Marsa, Ain Taya, Haraoua, Reghaia), as depicted in Figure 1.

The area covered $96.229 \mathrm{~km}^{2}$ and recorded a decline in the number population from 556487 people in 2008 to 665541 inhabitants in 2019 (Central Bureau of Statistics, 2019). Land morphology shows mostly flat areas, not exceeding 20 meters in height.

\section{Theory And Methodology}

\subsection{Theoretical framework}

It is essential to discuss certain points of view in the city's definition to understand the city's growth and development. A city is a large residential area inhabited by people of various social positions, whose livelihoods are mainly non-agricultural (Daldjoeni, 1987). In all countries globally, especially in developing countries, urban development occurs in urban areas(Lal, Kumar \& Kumar, 2017). The development of the city implies a physical change resulting from urban development. The city's development is determined by various factors, possibly improving the level of productivity and quality of life(Glaeser, Kallal, Scheinkman \& Shleifer, 1992). The concentric zone theory, initially proposed by Burgess, and others (1925), is a model of urban development that proliferates from its outward-extending center of origin. Meanwhile, the multi-core model deals with urban spatial development based on the theory of central growth originally proposed by Harris and Ullman (1945). The city's growth starts from a center to become a complex form caused by the appearance of new nuclei having the function of growth centers.

The downtown area is defined as a saturated area where residential growth has peaked. Downtown is the heart of a city that has gone from a residential area to a central business district, which functions as a center of economic activity, housing, and relatively comprehensive infrastructure types (Ferreira \& 
Condessa, 2012). Its central location has high accessibility due to rapid development. A vital indicator of the city's development is the increase in residential land.

\subsection{Material and Methods}

The primary and secondary data were relied on in this research. The primary data sources are Landsat 8 Operational Land Imager (OLI) and ThermalInfrared Sensor (TIRS) of the study area in 2014 and 2020. All Landsat images are downloaded from US Geological Survey (USGS) Earth Explorer (https://earthexplorer.usgs.gov/) and The Landsat program has been extensively used for ecosystem monitoring(Wulder et al., 2012). And the spectral signatures of remotely sensed data, for medium spatial resolution images, are still the most important features in land use/cover classification. At the optical analysis base, all images had the correct geometric coordinate and provided level-one terrain-corrected Landsat data in WGS84 geodetic datum, Universal Transverse Mercator Map projection (UTM, Zone 31N), due to the nature of the data the geometric and radiometric distortion were previously corrected before distribution(Rawat et al., 2013). And the individual scenes were processed according to through nearest neighbor technique.

To analyze changes in urban coverage over the past 6 years, post-classification comparisons and statistics are used. Based on the land cover properties in Algiers, we used the following four land cover types: Urban Land, Vegetation and Bare Lands, Water bodies

(Bouchachi \& Zhong, 2017).

The Secondary data sources include demographic data and administrative maps for the study area. To analyze the collected data, descriptive statistics and geospatial techniques were used.

\section{4.results And Discussion}

\subsection{Land use in the study area}

This research could highlight a change in land-use for all urban areas of Algiers. To accurately measure this phenomenon, we highlighted the necessary statistics. A central contribution to the study was the discovery of change. Medium-resolution images (2014-2020), such as Landsat, have allowed urban areas to be extracted (Figure 2), in comparison to data from the National Statistics Office.

The built-up area in 2014 was $77.26 \mathrm{~km}^{2}$ (45\% of the total area). After 06 years, it increased to $141.1 \mathrm{~km}^{2}$ ( $83 \%$ of the total area). The largest percentage of land use in the eastern Algiers area is for residential purposes, i.e. $62 \mathrm{~km}^{2}(80.5 \%)$ in 2014 and $94 \mathrm{~km}^{2}(66.6 \%)$ in 2020. Figure.2 shows land-use changes in the study area during the six years while.

The land conversion was noticed in some locations, namely in Beb Ezzouar, Berdj El Kiffan District, where land used for trade and services was turned into a residential area after programming the completion of housing projects for rent, beginning in the year 2013 (AADL) to absorb the housing crisis in the capital and eliminate random residential gatherings. It has also been observed that many agricultural areas have turned into industrial and service areas in the municipalities of Rouiba, Reghaia, Ain Taya, and Bab 
Ezzouar during the period (2014-2020). Which led to the consumption of agricultural areas significantly during the 6 years studied (Figure 3 and 4).

Therefore, Landsat Satellite spatial images were used from 2014 to 2020 to assess and adjust urbanization and transgression during this time frame. The analyses indicate that a very high urban density was seen in the study area. These expansions are primarily associated with the growth of new settlements, and these trends help us better understand urbanization patterns and processes and suggest some urbanization problems thus far. This increase in urbanization in areas, for example, has a negative impact on the ecosystems and services we provide, on the urbanization of these agricultural lands and natural habitats in urban areas, and thus on the cultural identity of cities. In the future, urban studies should take both generalities and character into consideration.

In urban areas, the main change in land cover is due to other types of land cover in land constructed because of construction and repairs, other changes are also very common, including increasing public green space and roads. Remote sensing is arguably the most efficient instrument for land cover monitoring and the most popular data sources on the urban scale are Landsat TM / ETM + and OLI data.

This section is distributed over six years from 2014 and 2020 to cover urban expansion in the study area: the spatial coverage for 2014 and 2020 is clearly shown in the figure. 5 .

We applied the Supervised Classification of land cover in the Landsat Images containing the Cities in the sample that typically extended beyond the set of districts containing these Cities, calculating the Urban Land of the study area. The urban grid for each city in the sample needed to be clipped using the Shapefile of the City District to calculate the Urban Land for each district in this set. Using the Arc Map's Raster Calculator with the municipal Shapefile set as an Analysis Mask, the urban grid was clipped.

We note that all the municipalities of the study area witnessed a significant expansion of urbanization at the expense of agricultural land, which makes it a $100 \%$ urban area, but the results here do not give an integrated idea of the drivers and factors of consumption, so it is necessary to include the indicator of the size of the population and the area consumed during the period (2014-2020) to clarify the relationship between population size and consumption of the area.

Table.1 Municipalities in terms of population density and consumption volume for the area (2014-2020) 


\begin{tabular}{|l|c|c|c|c|}
\hline Municipalities & Total area (H) & $\begin{array}{c}\text { Consumption Area } \\
\mathbf{( 2 0 1 4 - 2 0 2 0 )}\end{array}$ & Population $\mathbf{2 0 1 9}$ & $\begin{array}{c}\text { Density } \\
\mathbf{( P /} / \mathbf{k m} \mathbf{)})\end{array}$ \\
\hline Mohammadia & 794 & 71,46 & 62543 & 7876 \\
\hline Beb Ezzouar & 808 & 72,72 & 96597 & 11955 \\
\hline Dar El Beida & 3090 & 834,3 & 80033 & 2590 \\
\hline Bordj El Kiffan & 2218 & 421,42 & 151950 & 6850 \\
\hline Berdj El Bahri & 750 & 112,5 & 44665 & 5955 \\
\hline El Marsa & 3780 & 378 & 20250 & 535 \\
\hline Rouiba & 4109 & 822 & 61984 & 1508 \\
\hline Hraoua & 1250 & 375 & 27565 & 2205 \\
\hline Aine Taya & 967 & 193,4 & 34501 & 3567 \\
\hline Reghaia & 2695 & 808,5 & 85452 & 3170 \\
\hline
\end{tabular}

Source: Data Image LandSat 8(2014-2020) and(ONS) 2019.

From the table data, we can distinguish between municipalities that have expanded under demographic pressure and municipalities that consume the area significantly despite their small populations. And they are as follows:

- Municipalities with a high population density with significant reconstruction and consumption of the region, namely the -municipalities (Bordj El Kiffan, Beb Ezzouar, Dar El Beida, Reghaia).

- Highly populated municipalities and average consumption of the area (Hraoua and Rouiba)

Generally, as we have previously indicated in Figure 5 that all municipalities have experienced excessive consumption of the area. The worst types of consumption of the area are what occurs in municipalities that are not subject to any demographic pressure and yet they are over-consuming of the area, such as the municipality of Dar El Beida, Reghaia, and Rouiba, due to the growth of old industrial and service settlements as well as the establishment of new settlements in these municipalities.

Algeria, the main Algerian conglomerate, has seen its engineering develop rapidly over the past 30 years under the momentum of two main factors: management and manufacturing are concentrated in Algiers, and since 1990, a conflicting political situation. Added to these two factors could be the lack of developmental planning that would have ensured the smart organization of urban spaces and environmental protection. The introduction of a coherent city development policy that can reduce the effects of this phenomenon in the medium to long term depends on an assessment of the current dynamic and a prediction of future development in the Algiers region(Nedjai. et al., 2016)

Through Table 1, the Municipality of Dar El Beida is the most consumed area of approximately 834.3 hectares during the period (2014-2020) and an average density of $1504 \mathrm{P} / \mathrm{km}^{2}$, due to the existence of an industrial settlement within the urban fabric with an area of 51 hectares (22 factories for the food and mineral industry) in addition to the construction of a new international airport, which was started in 2006 for completion of the project in 2019, the airport consumed approximately 1200 hectares, followed by the municipality of Rouiba and Reghaia with 822 hectares and 808.5 hectares respectively, due to the allocation of 1000 hectares to the industrial zone (Rouiba -Reghaia), which is the largest industrial settlement in the study area in particular and the state of Algeria in general (Fig .6). 


\subsection{Characteristics and Risks of residential areas expansion}

Patterns of residential growth and development in the eastern Algiers region show that internal restructuring is characterized mainly by the filling or conversion of unbuilt land. However, residential areas also occupy the land, which was previously used for commercial and service activities, particularly in the form of job change from shopping complex buildings to mixed-use of residential, commercial, or service activities.

The dominantly horizontal residential expansion has occurred in the study area. Unfortunately, housing has also expanded to include unsuitable plots of land, namely conservation areas, disaster-prone areas, earthquake hazards, floods, industrial hazards, and environmental pollution in its various forms. In the face of these dangers that threaten all regions of Algeria in general and the study area in particular, accelerated reconstruction, which does not take into account this dimension, becomes a random act in which the population is at risk, and I will address the following seismic activity in the study area, In the following, I will address the seismic activity in the study area, which is witnessing a very large urban growth, despite the exposure of the study area to frequent and devastating earthquakes, the most recent of which was the 2003 earthquake.

The study area is located within the seismic range of Algeria characterized by the presence of several cracks and active fractures (continuous seismic waves generate), and seismic stations have classified the study area as a confined area between the coastal rift that extends from Thestate of Boumerdes to the state of Tibaza and the taseer rift that extends from the city of Isser to the city of Berdj El Bahri (Fig. 7).

After the 1985 Mexico earthquake, a team of seismologists concluded that sedimentary areas are more vulnerable to earthquakes and increased destructive effects, and since the study area is part of the Mitidja plain sedimentary, especially with active seismic cracks surrounding the Mitidja plain and the study area is particularly from different sides as illustrated by the map in Figure 7, and with the doubling of the area of urbanization as reached in this study during the period (2014-2020), the destructive effects of an earthquake will certainly be very large and Especially in areas where chaotic reconstruction prevails and where the rules of construction and reconstruction are not observed.

Generally, we cannot address all the risks to the study area in this paper, perhaps we can conduct future research to complement this article regarding the risks to the study area.

Through this study, there is a particular type of relationship between the expansion of the residential area and the distance from the CBD that is affected by the availability of land and the location of facilities. Research results show that the non-built-up area for residential development is almost non-existent. However, the trend in the period 2014-2020 delivers an essential lesson; that is, future residential expansion may go further and exploit even the unsuitable land. For this, all necessary measures and 
measures must be taken strictly to limit the random growth of residential areas and comply with the spatial plan of the city.

\section{Conclusions}

The eastern part of Algiers' city has witnessed unprecedented urbanization as a direct consequence of scalable economic development. The impacts of population pressure and the asymmetry between rural and urban areas have become patent in this study. Indeed, it is expected that the complexity of socioeconomic activity will directly impact population density, leverage issues related to land use, particularly agricultural land-use change, and the impacts of residential areas and commercial activity. One should note that the combined effects of Industry will also likely result in the inadequacy of maintaining agricultural land efficacy, leading to a complex problem of regional dimensions within one of the fastestgrowing cities in Northern Africa.

These combinatory effects can be measured well utilizing Geographic Information Systems and the assessment of urban sprawl and accounting for land use /land cover change. The adequate integration of a planning and monitoring structure can bring a multi-dimensional understanding that paves the way to a more coherent support system and enables spatial decision making along with regional growth parameters. Several key findings have clear spatial consequences and should be noted:

1. Urban sprawl is likely going to continue to happen with the increase of total urban footprint, and particularly the increment of Industrial land use.

2. The repercussions might directly impact economic development and population density, leading to an urban-centrism within the eastern part of the city.

3. The impacts on housing, infrastructure, and livability must be measured in line with previously existing industries to allow sustainable farming as an opportunity for a holistic integration of the combinations of residential land, Industrial land, and urban growth.

Throughout the rhetoric of developing countries in North Africa, it remains essential to assess a combinatory approach towards the traction of land-use change, considering the impacts of the urban footprint. There is strong evidence from a policy and planning perspective of using spatial analytical data to examine the change in terms of land use and economic activity. However, it is of utmost importance for cities such as Algiers to explore the regional impacts from a sustainability approach merging traditional economic activity sectors with the demands of urbanization and population change in the future. The potential risk within the scope of land-use change and geomorphological phenomena is evident, calling forth for combined spatial approaches that witness land use as a critical tool to foresight and plan cityscapes of tomorrow.

\section{References}


Aprillia Y., Pigawati B. (2018), Urban Sprawl Typology in Semarang City. Forum Geografi, 32(2). DOI: https://doi.org/10.23917/forgeo.v32i2.6369

Bagheri B., Tousi S. N. (2017), An explanation of urban sprawl phenomenon in Shiraz Metropolitan Area (SMA). Cities, (September), 1-20. DOI: https://doi.org/10.1016/j.cities.2017.10.011

Bouhennache. R, Bouden. T and Taleb. A. A.(2014), "Change Detection in Urban Land Cover Using Landsat Images Satellites, A Case Study in Algiers Town,", Tenth International Conference on SignalImage Technology and Internet-Based Systems, Marrakech, 2014, pp. 622-628, doi: 10.1109/SITIS.2014.57.

Bouchachi B., Zhong Y.(2017), Monitoring Urban Land Cover/land Use Change in Algiers City Using Landsat Images (1987-2016), ISPRS - International Archives of the Photogrammetry, Remote Sensing and Spatial Information Sciences, Volume XLII-2/W7, 2017, pp.1083-1090.

Bitta P., Nany Y., Fadjar H. M.(2019), Settlements Growth and Development in Semarang City Centre Area, Indonesia, Journal of Settlements and Spatial Planning, vol. 10, no. 2 , 99-109. DOI: https://doi.org/10.24193/JSSP.2019.2.03

Daldjoeni (1987), Geografi Kota dan Desa. Bandung: Alumni.

Donaghy M.M. (2013), Civil Society and Participatory Governance. Routledge. DOI: https://doi. org/10.4324/9780203098011

Ferreira J. A., Condessa B. (2012), Landscape and Urban Planning Defining expansion areas in small urban settlements - An application to the municipality of Tomar (Portugal). Landscape and Urban Planning, 107(3), 283-292. DOI: https://doi.org/10.1016/ j.landurbplan.2012.06.008

Glaeser E. L., Kallal H. D., Scheinkman J. A., Shleifer A. (1992), Growth in Cities. Journal of Political Economy, 100(6), 1126-1152.

Government of Ireland (2009), Guidelines for Planning Authorities on Sustainable Residential Development in Urban Areas.

Granath Hansson A. (2017), Promoting planning for housing development: What can Sweden learn from Germany? Land Use Policy, 64, 470-478. DOI: https://doi.org/10.1016/j.landusepol.2017.03.012

Hammond C W. (1985), Elements of Human Geography. Retrieved from https://books.google.co.id/ books?id=sWZ-AAAAMAAJ

Hudson F. S. (1974), Geography of Settlements. London: Mac Donald and Evans.

Keivani R., Werna E. (2001), Modes of housing provision in developing countries. Progress in Planning, 55(2), 65-118. DOI: https://doi.org/10.1016/S0305- 9006(00)00022-2 
Lal K., Kumar D., Kumar A. (2017), Spatiotemporal landscape modeling of urban growth patterns in Dhanbad Urban Agglomeration, India using geoinformatics techniques. Egyptian Journal of Remote Sensing and Space Science, 20(1), 91-102. DOI: https://doi.org/10.1016/j.ejrs.2017.01.003

Mahavir D. B. (1996), Modelling settlement patterns for metropolitan regions: inputs from remote sensing. ITC, Enschede, The Netherlands.

National Office of Statistics)ONS(, (2018), First Economic Census: final results of the firstphase. Statistical Collections N.172/2018.

Nedjai R, Bensaid A, Tuan VN, Haouchine A and Nasredine MN.(2016), Application of Remote Sensing and GIS to Assess the Construction Pressure on the Environment of Algiers (Algeria) During the Three Last Decades and Their Evolution by the Use of Markov Chain, J Remote Sensing \& GIS 2016, 5:2 DOI: $10.4172 / 2469-4134.100016$

Patino J. E., Duque J. C. (2013), A review of regional science applications of satellite remote sensing in urban settings. Computers, Environment and Urban Systems, 37(1), 1-17. DOI:

https://doi.org/10.1016/j.compenvur bsys.2012.06.003

Porter D. R. (2012), Managing growth in America's communities. Island Press.

Sarkar A. (2010), Analysis of Human Settlement Patterns Using RS and GIS in the Plains of West Bengal. The On-Line Indian Journal of Spatial Science, I (1).

Rawat J., Biswas V., \& Kumar M. (2013), Changes in land use/cover using geospatial techniques: A case study of Ramnagar town area, District Nainital, Uttarakhand, India. The Egyptian Journal of Remote Sensing and Space Science, 16(1), pp. 111-117.

Richardson H. (1993), Problems of metropolitan management in Asia. Urban Management: Policies and Innovations in Developing Countries, 51-75.

Sahana M., Hong H., Sajjad H. (2018), Analyzing urban spatial patterns and trend of urban growth using urban sprawl matrix: A study on Kolkata urban agglomeration, India. Science of the Total Environment, 628-629, 1557-1566. DOI: https://doi.org/10.1016/ j.scitotenv.2018.02.170

Seto K. C., Fragkias M., Güneralp B., Reilly M. K. (2011), A Meta-Analysis of Global Urban Land Expansion. PLoS ONE, 6(8), e23777. DOI: https://doi.org/10.1371/journal.pone.0023777

Werna E. (1998), Urban management, the provision of public services and intra-urban differentials in Nairobi. Habitat International, 22(1), 15-26. DOI: https://doi. org/10.1016/S0197-3975(97)00019-2

Wulder M. A., Masek J. G., Cohen W. B., Loveland T. R., Woodcock C. E. (2012), Opening the archive: How free data has enabled the science and monitoring promise of Landsat. Remote Sens Environ, 122, pp. 210. 
Figures
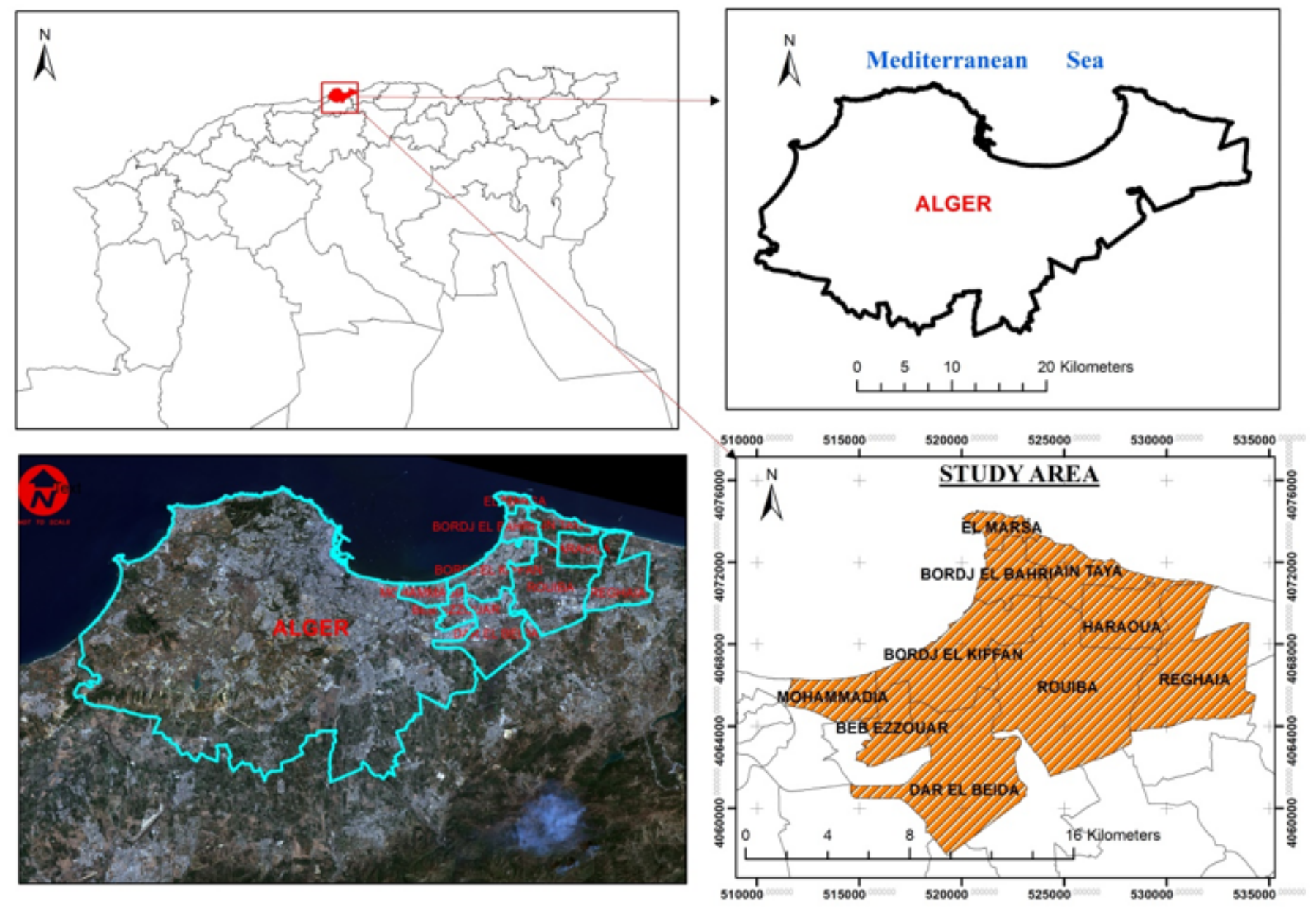

Figure 1

The Study Area of Algiers City in Northern Algeria. 


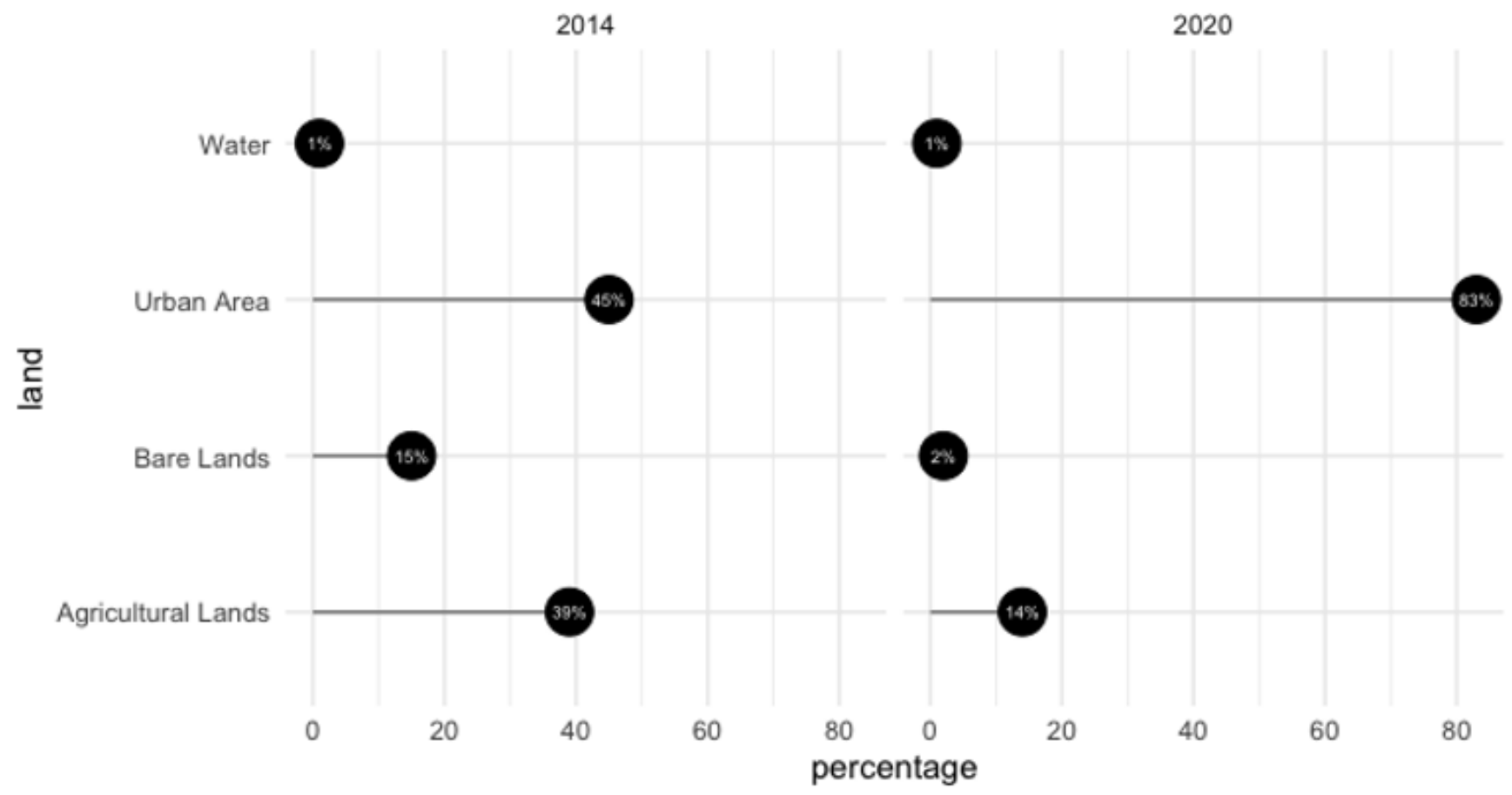

Source: Data Image LandSat 8(2014-2020).

\section{Figure 2}

Land use change in eastern Algiers city 2014 and in 2020.
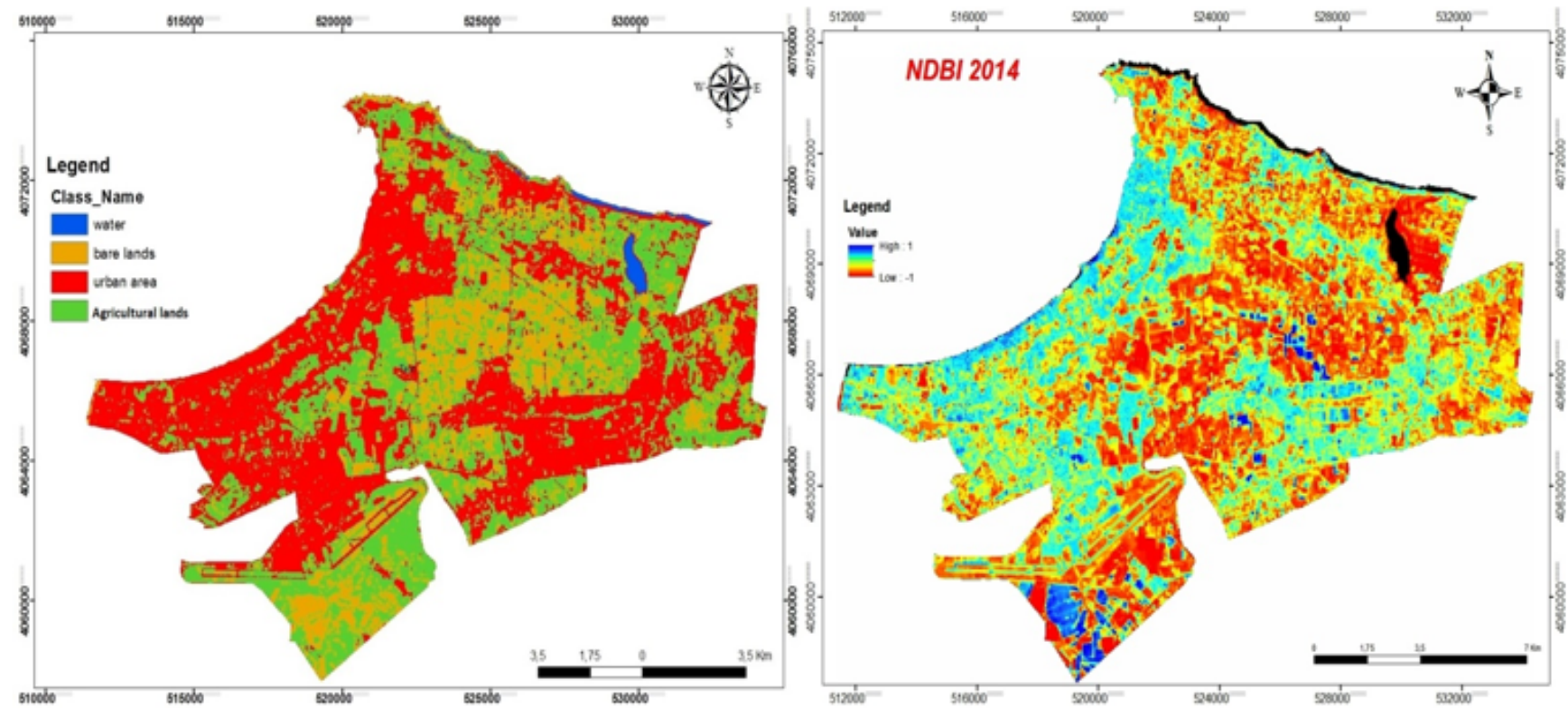

Figure 3

Urban Sprawl on Municipal Level 2014 

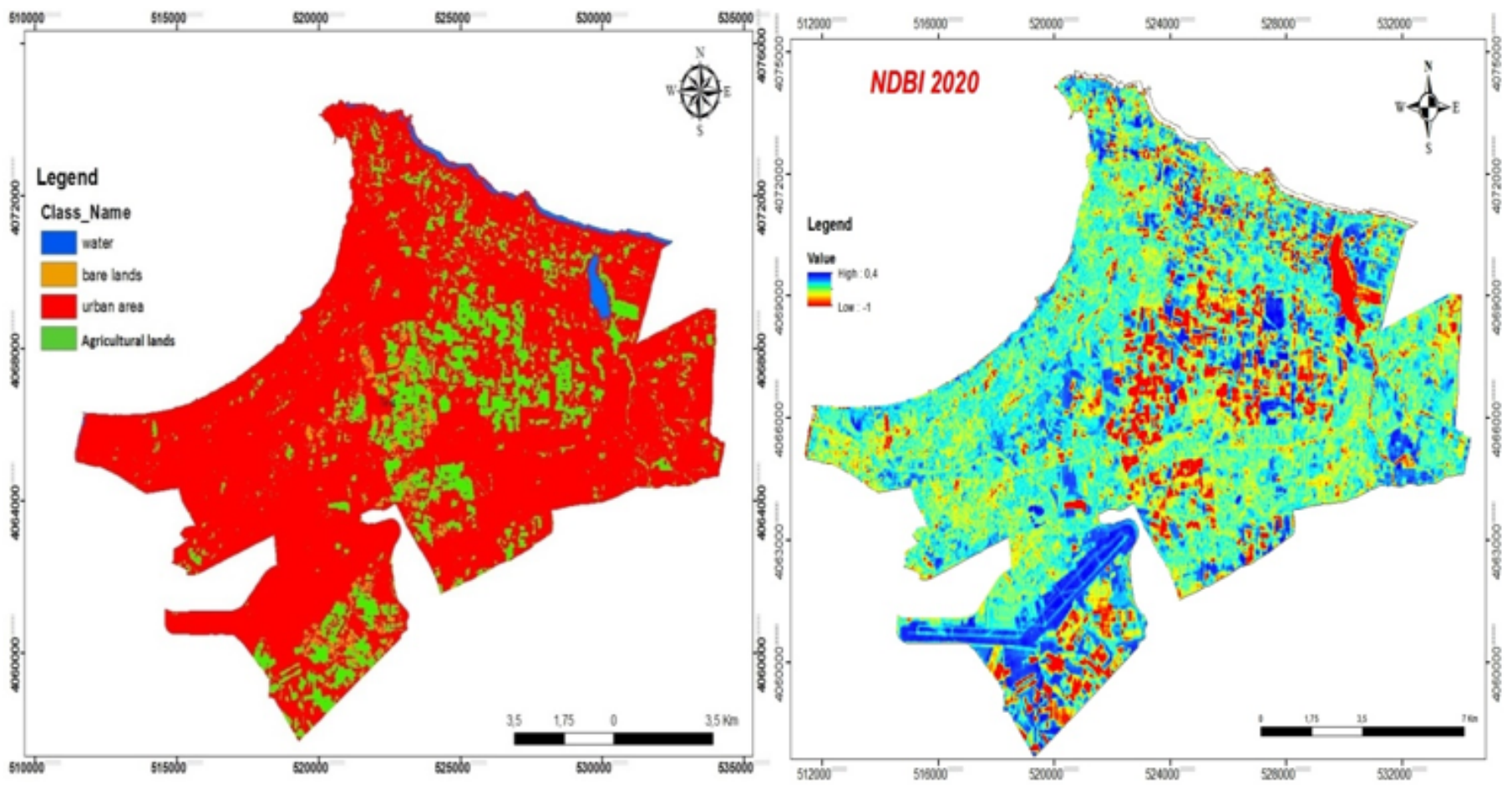

Figure 4

Urban Sprawl on Municipal Level 2020

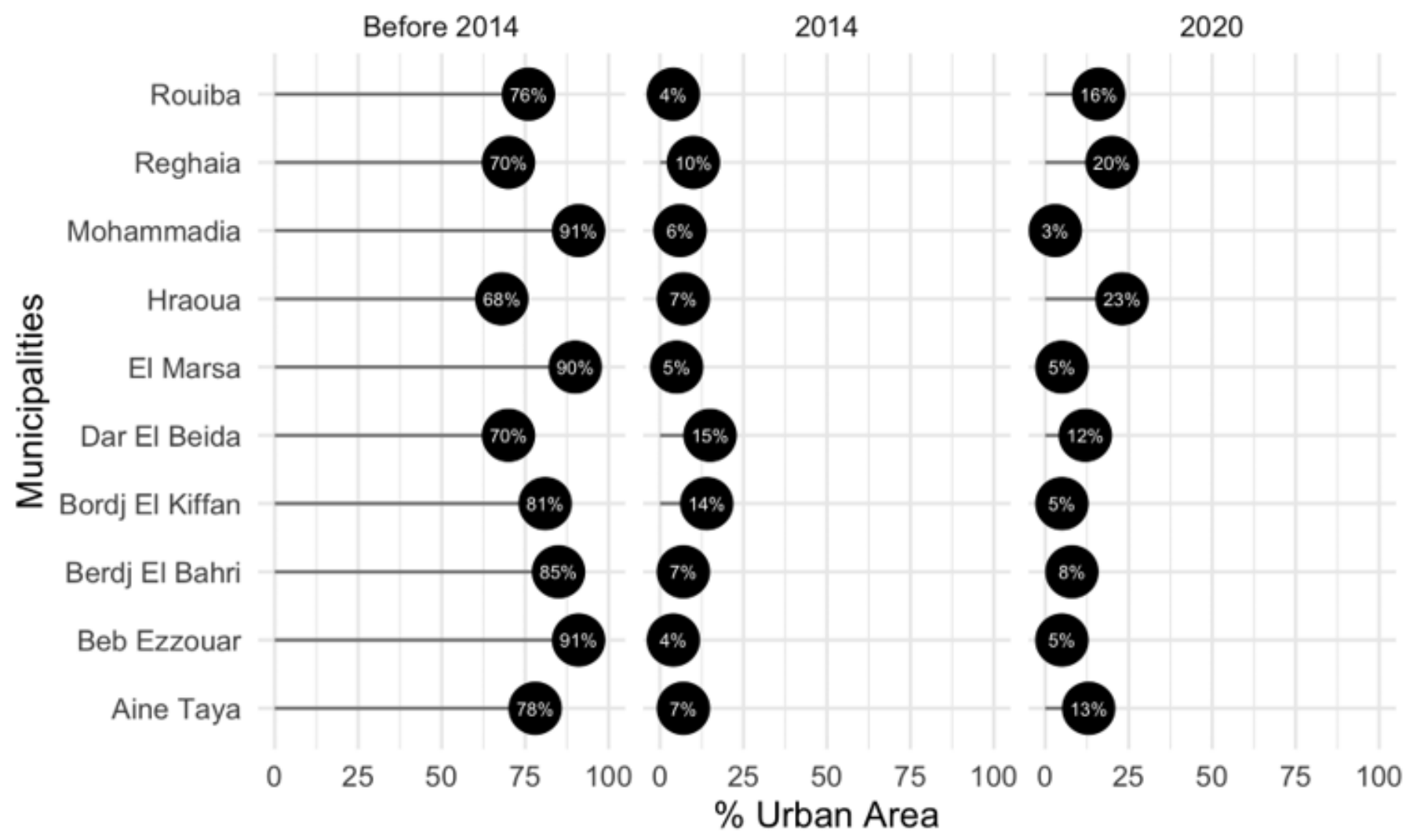

Source: Data Image LandSat 8(2014-2020). 
Figure 5

Urban Sprawl at the Municipal Level.
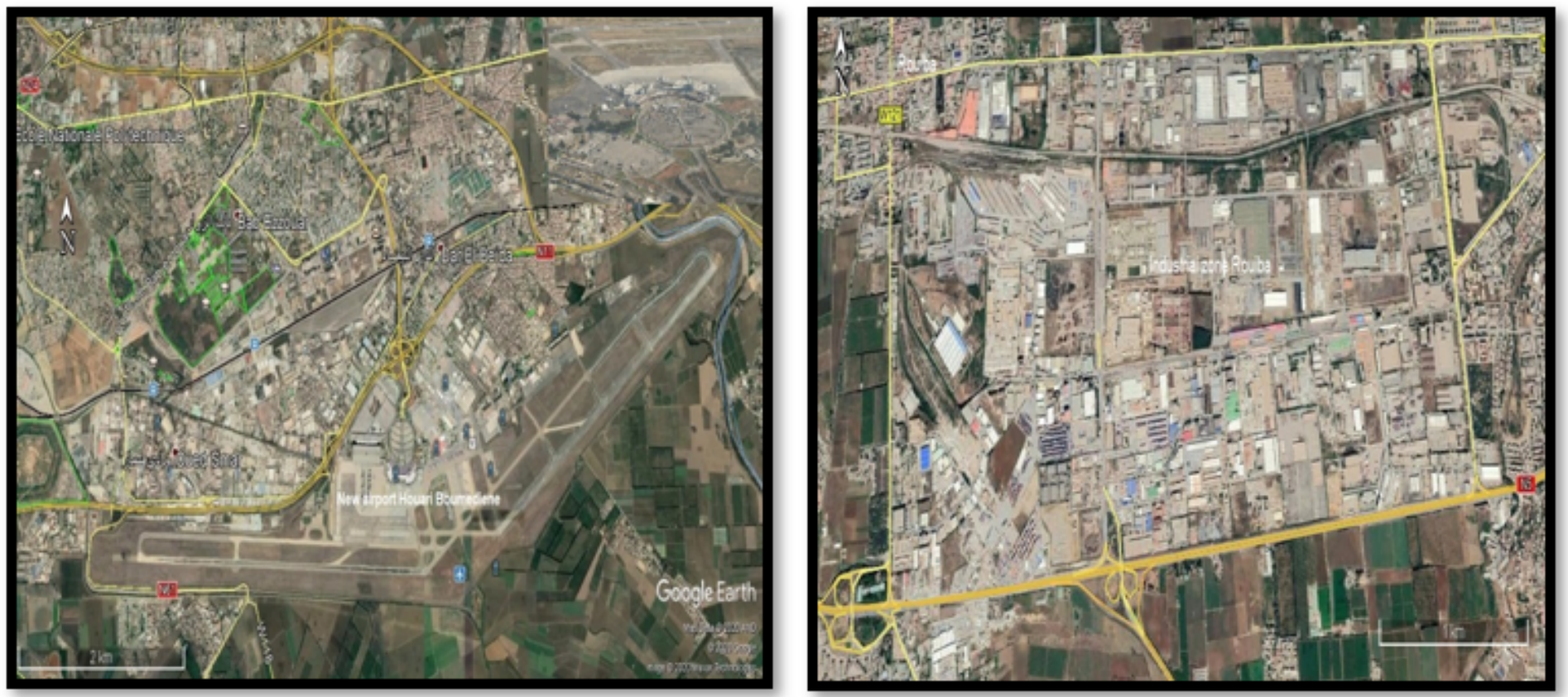

Source:Google Earth 15/10/2020.

\section{Figure 6}

The new airport, Houari Boumediene, and the Industrial zone of Rouiba.
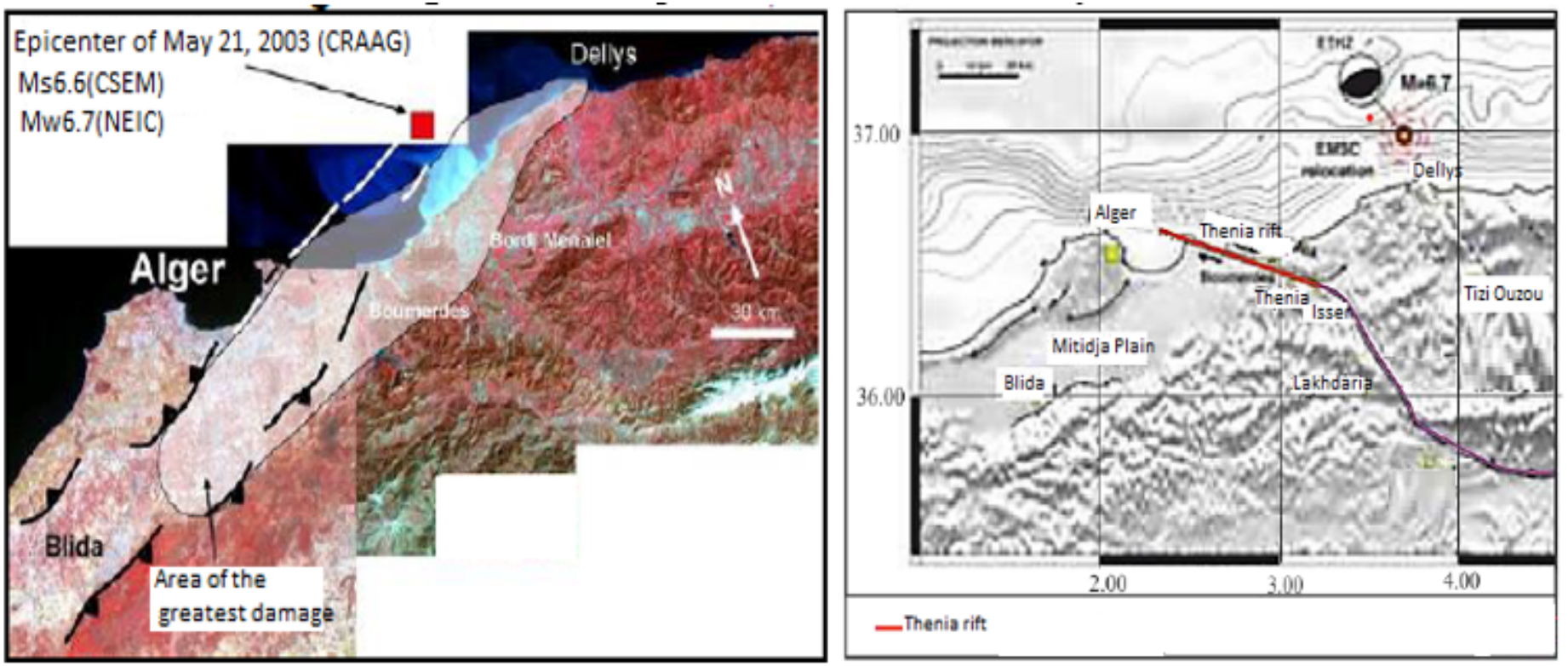

Source: Programme d'Aménagement Côtier (PAC)" MATET,2004 p17

Figure 7

Earthquake rift site for the study area. 